\title{
CZAS WOLNY JAKO JEDEN Z WYMIARÓW ŻYCIA CODZIENNEGO DZIECI MIESZKAJĄCYCH W POLSCE I W PORTUGALII
}

\begin{abstract}
Abstrakt: Celem artykułu jest ukazanie doświadczeń dzieci polskich i portugalskich w wieku wczesnoszkolnym dotyczących sposobów spędzania czasu wolnego po zajęciach w szkole. Liczne badania ukazują kurczenie się czasu wolnego w rodzinach oraz tendencję do coraz rzadszego przebywania na zewnątrz, w otoczeniu przyrody. Wielu badaczy na całym świecie dostrzega, iż korzystanie z mediów elektronicznych wypełnia nie tylko czas wolny dziecka, ale również czas zajęć obowiązkowych. Podjęta tematyka rzuca światło na współczesne tendencje związane z problematyką czasu wolnego.
\end{abstract}

Słowa kluczowe: czas wolny, mass media, dziecko, przyroda, deficyt natury

\section{WPROWADZENIE}

W okresie globalizacji czas wolny stał się obiektem rosnącego zainteresowania wielu dziedzin nauki: filozofii, antropologii, socjologii, psychologii, pedagogiki, architektury, ekonomii, a nawet medycyny. Zainteresowanie tego rodzaju problematyką wynika m.in. z przekonania, iż czas wolny jest nieodłącznym elementem biegu życia każdego człowieka, bez względu na jego wiek, płeć czy pochodzenie społeczne. Zwykle sprzyja zaspokajaniu różnych potrzeb jednostki, podnosi poziom i jakość życia, wywiera istotny wpływ na przebieg procesów społeczno-ekonomicznych, kulturowych i edukacyjnych - odgrywa ważną rolę w ewolucji świata. Przez ekonomistów zaliczany jest do ważnych wyznaczników kształtujących rozmiary i strukturę 
konsumpcji, stanowi nie tylko miernik osiągniętego dobrobytu, ale także fundamentalny czynnik rozwoju społecznego i gospodarczego.

$\mathrm{Na}$ wzorce spędzania czasu wolnego wpływ mają różnego rodzaju środowiska: naturalne, kulturowe i społeczne ${ }^{1}$. Wszystkie środowiska są ważne i względnie niezależne. W rzeczywistości są one ze sobą ściśle powiązane. Biorąc pod uwagę zdrowie człowieka - fizyczne i psychiczne - należy stwierdzić, że bardzo istotne jest środowisko przyrodnicze. Jeśli spojrzymy na nie w kategoriach wzajemnych związków i zależności, wówczas dostrzeżemy, że człowieka łączy z przyrodą więź życia: bliższe jest nam to, co żywe niż to, co martwe.

Badania nad sposobem spędzania wolnego czasu przez dzieci polskie i portugalskie wydają się interesujące chociażby z tego powodu, że pomagają uchwycić podobieństwa i różnice kulturowe w ramach oferowanych przez dorosłych form aktywności w czasie wolnym, rzucają światło na upodobania respondentów, ich marzenia, wartości oraz współczesne tendencje związane z problematyką czasu wolnego.

\section{POJĘCIE CZASU WOLNEGO}

Z punktu widzenia historycznego, o przełomu XIX i XX stulecia, kiedy to proletariat rozpoczął walkę o czas wolny, kojarzył się on wyłącznie z warstwami uprzywilejowanymi. Jednakże w efekcie dynamicznego rozwoju technicznego i społeczno-ekonomicznego oraz rozkwitu nauk medycznych czas wolny uległ upowszechnieniu i stał się udziałem wszystkich członków społeczeństwa (Pabian 2010, s. 340). Progres gospodarczy oraz narodziny społeczeństwa industrialnego sprawiły, że czas zyskał nowe oblicze - został podzielony na czas pracy i czas niekwestionowanego wypoczynku (Cieloch, Kuczyński, Rogoziński 1992, s. 7). W waloryzacji człowieka zaczęto doceniać zarówno jego pracę, jak i kulturę czasu wolnego. Współcześnie brak pracy i stopniowy proces wykluczania społecznego rodziny prowadzą do

${ }^{1}$ W literaturze naukowej pojęcie środowiska jest różnie definiowane. Pedagogika społeczna środowiskiem nazywa te elementy rzeczywistości, które działają na człowieka jako źródło bodźców i powodują określone reakcje (przeżycia) psychiczne. Środowisko jest układem złożonym z wielu elementów wzajemnie powiązanych i zależnych od siebie (Wroczyński 1974, s. 76). Biorąc pod uwagę podział ze względu na genezę i charakter bodźców, wyodrębnia się trzy rodzaje środowisk:

1. Srodowisko naturalne (geograficzne) - obejmuje ziemię z jej zasobami i ukształtowaniem, klimat, florę oraz faunę; środowisko to nie stanowi tylko dzieła natury, ale jest także w mniejszym lub większym stopniu przekształcone przez gospodarczą działalność człowieka;

2. Środowisko kulturowe - obejmuje dorobek człowieka w ujęciu historycznym, dotyczącym sfery materialnej (przedmiotów) oraz duchowej (poglądów człowieka, norm i zasad);

3. Środowisko społeczne - obejmuje ludzi i stosunki społeczne w nim występujące (Encyklopedia pedagogiczna XXI wieku 2007, s. 432). 
deformacji postrzegania czasu wolnego. Zacierają się i przenikają charakterystyczne dla nowoczesnego społeczeństwa granice podziału między czasem pracy a czasem wolnym. „Ta sama czynność, która dla jednych oznacza wolność, dla drugich jest obowiązkiem” (Klein 2009, s. 208). Jak zauważa Maria Truszkowska-Wojtkowiak (2012, s. 8), „czas wolny oscyluje między czasem sacrum a profanum oraz między upodmiotowieniem i uprzedmiotowieniem, by stać się wieloaspektowym fenomenem bycia wolnym".

Badacze zajmujący się pojęciem czasu wolnego próbują usystematyzować wiedzę na jego temat i stworzyć spójną koncepcję. Dlatego w różnych definicjach pojęcia szukają elementów wspólnych. Ze względu na akcentowane aspekty, definicje czasu wolnego możemy podzielić na (Gagacka 2007, s. 122):

1. Psychologiczno-subiektywne: czas wolny jako sposób, styl postępowania, stan duszy, stosunek do wykonywanej czynności.

2. Rezydualne (pozostałe z czegoś, po czymś): czas wolny jako czas pomniejszony o obowiązki.

3. Autonomiczno-osobiste: czas wolny jako czas przeznaczony na czynności dobrowolne.

4. Normatywno-funkcjonalne: czas wolny jako czas wykorzystany w konkretnym celu, np. wypoczynku, kreowania siebie, pogłębiania wiedzy.

5. Behawioralne: czas wolny jako czas interpretowany przez pryzmat specyficznych zachowań, które prowadzą do odpoczynku.

6. Ekonomiczne: czas wolny jako czas, który nie jest sprzedawany i należy do jednostki bez względu na sposób wykorzystania.

Maria Czerepaniak-Walczak (2007, s. 219-236) rozróżnia trzy typy definicji czasu wolnego:

1. Strukturalne - akcentują czynności wykonywane (bądź nie) w czasie wolnym, np. swobodne „wczasowanie”, aktywność sportowa.

2. Funkcjonalne - podkreślają funkcje czasu wolnego, to, czemu ten czas ma służyć, np. doskonaleniu osobowości, odpoczynkowi.

3. Atrybutywne - odnoszą się do pojedynczego człowieka, do cech specyficznych dla definiowanego zjawiska, podkreślają antropocentryzm i podmiotowość, akcentują moc sprawczą jednostki.

W opinii Czerepaniak-Walczak (2007, s. 236):

czas wolny jest tym interwałem podmiotowego życia, w którym osoba doświadcza dobrostanu intelektualnego, emocjonalnego i fizycznego, w rezultacie możliwości samodzielnego, suwerennego przejawiania czynności posiadających znamiona dobrowolności i niekomercyjności oraz będących źródłem satysfakcji. 
Definicja ta podkreśla atrybuty czasu wolnego, a konkretnie czynności w nim wykonywanych: dobrowolność (dowolność), niezarobkowość oraz przyjemność, przy czym, autorka twierdzi, iż jedynie w przypadku gdy dany czas jest wypełniony zachowaniami i stanami spełniającymi wszystkie trzy warunki, może nosić miano czasu wolnego.

Czas wolny, w zależności od koncepcji, jaką przyjmuje badacz, może być pojmowany instrumentalnie (mechanicznie) bądź jako wartość autoteliczna (Kazimierczak 2007, s. 15-21). Pojmowanie instrumentalne wyraża się w traktowaniu czasu wolnego jako środka do osiągania celów. Akcent przeniesiony jest na ustalanie budżetu czasu, a nie na wykorzystanie potencjału rozwojowego człowieka. Marek Kazimierczak sygnalizuje, że instrumentalne traktowanie czasu wolnego oznacza zdominowanie człowieka przez konsumpcję i sterowanie nim. Podejście autoteliczne jest o tyle różne, iż pozwala traktować czas wolny jako wartość samą w sobie, jako cel. Wypełnienie go takimi aktywnościami jak kontemplacja, refleksja czy tworzenie kultury sprawia, że jest warunkiem rozwoju osobowości - „staje się celem, bowiem oznacza realizację wartości autotelicznych - prawdy, piękna, dobra” (Kazimierczak 2007, s. 19).

Chociaż definicji czasu wolnego istnieje wiele, to na ogół jest on rozumiany jako ten czas, który pozostaje człowiekowi do swobodnej dyspozycji po wykonaniu czynności służących zaspokojeniu potrzeb biologicznych, higienicznych oraz czynności obowiązkowych związanych z pracą, nauką, rodziną (Przecławski 1993, s. 75). Czas wolny to czas nieskrępowanego wyboru form wypoczynku, rozrywki, zainteresowań odpowiadających jednostce i mających na celu regenerację sił zużytych w trakcie nauki, wykonywania pracy bądź innych czynności, poprawę stanu zdrowia, rozwój psychiczny, fizyczny i duchowy - rozwój własnej osobowości. Czas wolny zaczyna się wtedy, gdy kończy się czas pracy, a człowiek nie podlega żadnym przymusom społecznym² ${ }^{2}$.

Przyjęta forma spędzenia czasu wolnego wyznacza określone zajęcia i spełnia różne funkcje, z których najczęściej wymieniana jest rekreacyjna i zabawowa (Truszkowska-Wojtkowiak 2012, s. 116). Marian Grochociński (1980, s. 8) oprócz funkcji pozytywnych, takich jak: twórcza, percepcyjna (rozwija osobowość przez poznawanie i odbiór cudzej twórczości), rekreacyjna, uspołeczniająca, wymienia również patologiczną, którą pełnią zajęcia oddziałujące na uczestników zajęć negatywnie.

2 W tym znaczeniu czas wolny nie istniał w społeczeństwach pierwotnych, które przerwy w pracy wypełniały zbiorowymi obrządkami świątecznymi. Nie istnieje też w społeczeństwach rolniczych, w których wypoczynek i praca przeplatają się. Paul Lafargue - filozof marksistowski, działacz i teoretyk francuskiego oraz międzynarodowego ruchu robotniczego - walczył o prawo do lenistwa (manifest pod tym tytułem wydał w 1883 roku). Okres twórczego lenistwa, niezbędny, by oddać się refleksji i zdobyć mądrość, szczególnie cenili starożytni Grecy, odnoszący się z pogardą do pracy, zwłaszcza fizycznej. Piewcami czasu wolnego byli również renesansowi humaniści (Durozoi, Roussel 1997, s. 55). 


\section{DZIECKO W ŚWIECIE ŻYCIA CODZIENNEGO I W ŚWIECIE PRZYRODY}

Pojęcie świat ma wiele znaczeń. Jest definiowane jako ogół przedmiotów, które tworzą kosmos lub wszechświat. Niekiedy słowem świat oznacza się tylko nasz układ planetarny, a więc jedynie część wszechświata (w tym sensie mówi się o wielu światach). Słowo to odnosi się także do człowieka i ogółu stanów jego świadomości. W tym znaczeniu świat wewnętrzny przeciwstawia się światowi zewnętrznemu, zbiorowi zjawisk zmysłowych (Durozoi, Roussel 1997, s. 282). Według Martina Bubera (1968, s. 448) świat „rodzi w jednostce osobę. Świat, którym jest całe otoczenie, natura oraz społeczeństwo, wychowuje ludzką istotę: wydobywa jej siły i pozwala jej uchwycić oraz przeniknąć to, z czym ona się spotyka”. W rozważaniach Józefa Tischnera (1989, s. 19 ) czytamy:

Człowiek zajmuje miejsce w środku świata zjawisk, które są zjawiskami dla niego. Zjawiska, dzięki sensowi, a więc dzięki stanowiącym je istotom, wiążą się, mniej lub bardziej, ze sobą. Ich całość stanowi świat otaczający człowieka. Mój świat jest utkany ze znaczeń. Związek jednego przedmiotu z drugim w tym świecie jest związkiem czegoś - do czegoś - ze względu na - coś.

Świat życia codziennego „stanowi zarówno scenę, jak i obiekt naszych działań i interakcji. Musimy nad nim panować, jak również zmieniać go w celu realizacji własnych zamiarów, w jego ramach i pośród naszych bliźnich" (Schütz 2008, s. 18). Człowiek w świecie życia działa aktywnie nie tylko wobec przedmiotów nieożywionych, ale również wobec innych osób, które powodują jego działania, i które on skłania do reakcji. „Świat każdego człowieka jest niepowtarzalny, jest inny, uwarunkowany jedynością zajmowanego w bycie miejsca" (Szpet 2013, s. 31). Według Alfreda Schütza (2008, s. 71) człowiek w sposób naturalny w pierwszej kolejności zainteresowany jest fragmentem codziennego życia znajdującym się w jego zasięgu i koncentrującym się wokół niego czasowo i przestrzennie.

Bycie w świecie oznacza zanurzenie człowieka w świecie rzeczy, przyrody ożywionej i nieożywionej, w świecie kultury, którego sam jest twórcą, zanurzenie w świecie drugiego człowieka i we własnym świecie przeżyć. Współczesne dzieci „budują swój dziecięcy Lebenswelt, świat przeżywany” (Smolińska-Theiss 2014, s. 11) na bazie własnych doświadczeń i odczuć, wyobrażeń i spostrzeżeń oraz powszechnie obowiązujących norm i zasad.

Na sposób spędzania czasu wolnego przez dzieci wpływ mają przestrzenie i miejsca wypełnione określonymi treściami i wartościami, a ich jakość i dostępność zależy głównie od wiedzy, przekonań i preferencji dorosłych, którzy zawłaszczają dzieciństwo i starają się panować nawet nad tym, co dotychczas było tajemnicą 
dzieciom tylko znaną. Tendencje do nieskrępowanego działania w wybranych przez siebie środowiskach - szczególnie w okresie dzieciństwa - są zwykle przez dorosłych ograniczane. Zdaniem wielu badaczy „pozostawione samym sobie dzieci najbardziej ciągnie do dzikich obrzeży parków, do wąwozów i skalistych górek, do dzikiej roślinności" (Louv 2014, s. 148). Autor książki Ostatnie dziecko w lesie stwierdza, że dzieci potrzebują nieskrępowanego bycia w przyrodzie „w takim samym stopniu, jak niezbędne jest im właściwe odżywianie czy odpowiednia ilość snu" (Louv 2014, s. 16). Tymczasem współcześnie bawią się one na dworze rzadziej i krócej, nie oddalają się prawie od domu, mają mniejszą liczbę towarzyszy zabaw, w zamian coraz więcej czasu spędzają w domach i na siedzeniach samochodów (Louv 2014, s. 52-53).

Kontakt dziecka z naturą jest konieczny do jego rozwoju psychofizycznego, ponieważ stanowi główne źródło bodźców zmysłowych, doskonali pamięć, wyobraźnię i kreatywność, budzi ciekawość i instynktowną pewność siebie, motywuje do uczenia się, poprawia relacje rówieśnicze, obniża poziom stresu i wpływa na polepszenie kondycji fizycznej. Świat przyrody jest wręcz niezbędny do istnienia człowieka, nie tylko z powodu pożywienia, wody i czystego powietrza, ale także innych korzyści, związanych głównie ze zdrowiem i kulturą. Jednakże nie zawsze w pełni się je docenia, ponieważ nie trzeba za nie płacić. Jak słusznie zauważa Richard Louv (2014, s. 148), „dzieciństwo pozbawione kontaktów z przyrodą traci swoją istotę", bowiem natura otwiera przed każdym dzieckiem starodawny, bezgraniczny, nieprzejrzany świat usytuowany poza kontrolą rodziców.

\section{CZAS WOLNY DZIECI POLSKICH I PORTUGALSKICH - ANALIZA WYNIKÓW BADAŃ WŁASNYCH}

Literatura podejmująca problematykę wolnego czasu współczesnych dzieci bardzo rzadko odnosi się do aspektów miejsc i przestrzeni ${ }^{3}$. Wprowadzeniem do rozważań dotyczących podejmowanych przez respondentów form aktywności w czasie wolnym oraz preferowanych rozwiązań przestrzennych są badania, które dają odpowiedzi na cztery ważne pytania:

1. Jak dzieci w wieku wczesnoszkolnym interpretują pojęcie czasu wolnego?

2. Jakie przestrzenie i miejsca preferują współczesne dzieci, mieszkające w Polsce i w Portugalii, w czasie wolnym?

3 Interesujące badania dotyczące funkcjonowania dzieci mieszkających w Szwecji, w wieku od 10 do 12 lat, w szkole oraz poza jej terenem opisuje Katarina Gustaffson. Prowadzone były przez dość długi czas w środowisku szkolnym i pozaszkolnym, zgodnie z metodologią etnograficzną (Gustaffson 2009, s. 83-101). 
3. Jakiego rodzaju aktywności preferują współczesne dzieci, mieszkające w Polsce i w Portugalii, w czasie wolnym?

4. Jakie opinie wyrażają respondenci na temat osobistych doświadczeń $\mathrm{z}$ przyrodą?

Podstawową metodą badań był przeprowadzony wśród dzieci sondaż diagnostyczny. Opracowany kwestionariusz wywiadu składał się z 12 pytań (dominowały otwarte). Badania miały na celu ustalenie zasobu wiedzy dzieci na temat czasu wolnego i ich doświadczeń w tym zakresie, odkrycie i poznanie organizacji dnia oraz specyfiki podejmowanych w czasie wolnym form aktywności uczniów dziewięcioletnich uczęszczających do szkół podstawowych na terenie Polski (50 osób) ${ }^{4}$ oraz Portugalii (48 osób) $)^{5}$. Dobór próby badawczej odbył się w sposób celowo-losowy. Losowo został wybrany teren badań, natomiast grupę badawczą dobrano w celowo, kierując się wykształceniem, sytuacją zawodową i materialną rodziców. Zarówno w grupie polskiej, jak i portugalskiej zdecydowana większość rodziców posiadała wykształcenie średnie (w nielicznych przypadkach wyższe), a sytuacja zawodowa i materialna została oceniona jako dobra (w kilku przypadkach przeciętna).

\section{ROZUMIENIE POJĘCIA CZASU WOLNEGO PRZEZ DZIECI POLSKIE I PORTUGALSKIE}

Wypowiedzi badanych dzieci - mieszkających w Polsce i w Portugalii - wskazują na to, że na ogół czas wolny jest przez nie postrzegany jako czas spędzony poza szkołą. Zdecydowana większość respondentów utożsamia czas wolny z wszelkimi formami działalności związanymi m.in. z: wykonywaniem zadań domowych, uczęszczaniem na korepetycje, różnymi zajęciami dodatkowymi, jak również tymi, które wynikają z pomagania rodzicom w prowadzeniu wspólnego gospodarstwa domowego. Jest to czas precyzyjnie zaplanowany przez instytucje i/lub rodziców, kontrolowany, czyli pozornie wolny.

Jedynie znikoma grupa badanych stwierdza, że czas wolny to taki czas, który nie jest wypełniony obowiązkami lub innymi czynnościami oferowanymi głównie przez dorosłych. Jest to czas przeznaczony wyłącznie do ich dyspozycji, wypełniony najczęściej zabawą z przyjaciółmi lub z ulubionymi zwierzętami, różnymi grami, sportem czy zwyczajnym leniuchowaniem.

\footnotetext{
4 Badania przeprowadzono w maju 2015 roku w szkołach podstawowych usytuowanych w miastach powiatowych województwa lubelskiego.

5 Badania zostały przeprowadzone w kwietniu 2015 roku w placówce oświatowej Escola Básica e Jardim de Infância Raúl Lino no Monte Estoril w ramach seminarium edukacyjnego, które odbywało się w Lizbonie.
} 
Wydaje się, że dawniej dzieci miały więcej wolnego czasu na taką aktywność jak gry terenowe, gry w piłkę, spacery oraz spotkania ze znajomymi. Obecnie tego czasu mają coraz mniej, choćby ze względu na fakt, iż współczesny świat staje się coraz bardziej wymagający, oferujący wiele działań edukacyjnych, które niewiele mają wspólnego z czasem wolnym. Tymczasem wśród wielu potrzeb, jakie mają dzieci portugalskie i polskie, znajduje się potrzeba czasu wolnego - spędzanego na swój sposób, według własnego pomysłu, w wybranym przez siebie miejscu. Warto zauważyć, że w wypowiedziach respondentów odnoszących się do rozumienia analizowanego pojęcia nie dostrzeżono radykalnych różnic.

\section{PRZESTRZENIE I MIEJSCA AKTYWNOŚCI W CZASIE WOLNYM}

Współczesne teorie psychologiczne akcentują, że rozwój trwający przez całe życie dokonuje się w toku aktywnego kontaktu ze środowiskiem społeczno-przyrodniczym i kulturowym (otaczającą rzeczywistością). Jak podaje Augustyn Bańka (2002, s. 26), „wpływ człowieka na środowisko odbywa się poprzez świadome działania, takie jak projektowanie architektoniczne, planowanie urbanistyczne, różnorodne użycie przestrzeni w rekreacji lub pracy [...]”. Urie Bronfenbrenner stwierdza, że dziecko i jego otoczenie wpływają na siebie wzajemnie w sposób dwukierunkowy, czyli transakcyjny (Vasta, Haith, Miller 1995, s. 73). Jego teoria systemów ekologicznych kładzie nacisk na związki między jednostką a poszczególnymi warstwami składającymi się na jej środowisko. Najbliżej dziecka znajduje się mikrosystem - rodzina, sąsiedzi, przedszkole plac zabaw, biblioteka, kościół - poszerzający się wraz z kontaktami, jakie dziecko nawiązuje, przebywając w tych miejscach. Mikrosystem zmienia się w miarę dorastania. Związki między mikrosystemami tworzą mezosystem, np. relacje z innymi osobami. Systemy społeczne, np. władze lokalne, zakłady pracy, instytucje, tworzą egzosystem. Kultura i podkultura, w których żyje dziecko, tworzą makrosystem będący nośnikiem przekonań, postaw i tradycji. Kontakt z otoczeniem to źródło wielorakich nowych doświadczeń jednostki, które podlegają rozwojowi, są podstawą tworzenia i przekształcania umysłowych struktur poznawczych (Tyszkowa 1988, s. 48). Przestrzeń i miejsce - pojęcia, które znamy z codziennych doświadczeń - są zasadniczymi składnikami naszego świata. Według Yi-Fu Tuana (1987, s. 75) - uważanego za humanistycznego geografa - przestrzeń to neutralny zespół zdarzeń, przedmiotów i wymiarów. Jest symbolem wolności, zachęca do działania, a odczuwana przez jednostkę jako doskonale znana staje się miejscem. Przestrzeń charakteryzuje się różnym stopniem dostępności. Może być otwarta lub zamknięta, otoczona granicami ściśle określonymi, 
umownymi lub symbolicznymi. Przestrzenie i miejsca aktywności badanych dzieci w czasie wolnym przedstawia tabela 1 .

Tabela 1. Rodzaje przestrzeni i miejsc aktywności dzieci w czasie wolnym

\begin{tabular}{|l|c|c|c|}
\hline \multicolumn{1}{|c|}{ Kategorie } & $\begin{array}{c}\text { Dzieci polskie } \\
\mathrm{N}=50\end{array}$ & $\begin{array}{c}\text { Dzieci portugalskie } \\
\mathrm{N}=48\end{array}$ & $\begin{array}{c}\text { Razem } \\
\mathrm{N}=98\end{array}$ \\
\hline Przestrzenie i miejsca wewnątrz budynków & $72 \%$ & $62,5 \%$ & $69,4 \%$ \\
\hline Przestrzenie i miejsca na zewnątrz budynków & $28 \%$ & $37,5 \%$ & $30,6 \%$ \\
\hline
\end{tabular}

Źródło: opracowanie własne.

Jak pokazują dane, blisko 70\% respondentów w czasie pozaszkolnym przebywa w przestrzeniach i miejscach wewnątrz budynków takich jak: mieszkania, kluby sportowe, centra kultury, markety, muzea, kina oraz restauracje. Pozostałe dzieci (ponad 30\%) preferują przestrzenie i miejsca na zewnątrz budynków: ogrody lub podwórka, ulice, lasy, parki, plaże, ścieżki rowerowe oraz inne miejsca zabaw w naturze (kryjówki, zakamarki). Wskazane przez respondentów mieszkających w Polsce i w Portugalii różnice między czasem wolnym spędzanym wewnątrz budynków a czasem wolnym spędzanym na zewnątrz są nieznaczne - wynoszą około $10 \%$. W przypadku przestrzeni i miejsc wewnątrz budynków zarówno dzieci portugalskie, jak i polskie najwięcej czasu wolnego spędzają w domach oraz mieszkaniach - swoich lub innych osób. Jeśli chodzi o przestrzenie i miejsca na zewnątrz budynków, uczniowie portugalscy wybierają pobyt na plażach i ścieżkach rowerowych, natomiast dzieci polskie - zabawy na podwórkach i osiedlowych placach zabaw. Ważnym czynnikiem, który niewątpliwie różnicuje wypowiedzi respondentów w powyższej kwestii, jest położenie geograficzne ${ }^{6}$ i związane z nim osobliwości fizyczne, przestrzenne i społeczno-gospodarcze terenu badań.

Rodzaje aktywności podejmowane zazwyczaj po zajęciach w szkole przez dzieci polskie i portugalskie ukazuje tabela 2 .

W pozaszkolnej aktywności respondentów polskich i portugalskich można dostrzec zarówno różnice, jak i podobieństwa co do rodzaju oraz zakresu podejmowanych działań. Z zebranych danych wynika, że więcej niż połowa badanych dzieci portugalskich $(66,7 \%)$ przeznacza czas wolny na naukę w domu, a 33\% respondentów uczęszcza na korepetycje - głównie z języka angielskiego, hiszpańskiego, niemieckiego i matematyki. Zapewne trudna sytuacja społeczno-ekonomiczna Portugalii i związany z nią kurczący się rynek pracy powodują, iż wielu

${ }^{6}$ Monte Estoril to mała miejscowość obok Estoril, miasta i kurortu wypoczynkowego w portugalskiej gminie Cascais, na zachód od Lizbony, znanego z urokliwych plaż. 
rodziców decyduje się na duże wyrzeczenia, aby tylko dobrze wykształcić dziecko i zwiększyć w ten sposób jego szanse na zatrudnienie i godziwą płacę. W Polsce odsetek badanych dzieci deklarujących spędzanie czasu wolnego na odrabianiu lekcji wynosi $32 \%$, a na korzystaniu z dodatkowych zajęć - $6 \%$.

Tabela 2. Rodzaje aktywności dzieci w czasie wolnym

\begin{tabular}{|l|c|c|}
\hline \multicolumn{1}{|c|}{ Aktywności } & $\begin{array}{c}\text { Dzieci polskie } \\
\mathrm{N}=50\end{array}$ & $\begin{array}{c}\text { Dzieci portugalskie } \\
\mathrm{N}=48\end{array}$ \\
\hline Odrabianie lekcji & $\mathbf{3 2 \%}$ & $\mathbf{6 6 , 7 \%}$ \\
\hline Korepetycje & $\mathbf{6 \%}$ & $\mathbf{3 3 , 3} \%$ \\
\hline Oglądanie telewizji/gry komputerowe & $\mathbf{4 4 \%}$ & $\mathbf{3 1 , 3 \%}$ \\
\hline Trening & $6 \%$ & $\mathbf{2 9 , 2} \%$ \\
\hline Zabawy z użyciem tabletu & $16 \%$ & $16,7 \%$ \\
\hline Pobyt na plaży & - & $16,7 \%$ \\
\hline Jazda na rowerze & $12 \%$ & $16,7 \%$ \\
\hline Pisanie e-maili i SMS-ów & $8 \%$ & $16,7 \%$ \\
\hline Zabawy w ogrodzie/na podwórku/na placu zabaw & $18 \%$ & $12,5 \%$ \\
\hline Zabawa z rodzeństwem/rówieśnikami & $12 \%$ & $12,5 \%$ \\
\hline Czytanie & $8 \%$ & $8,3 \%$ \\
\hline Zabawy/spacer z psem & $8 \%$ & $4,2 \%$ \\
\hline Wyjścia do restauracji & - & $4,2 \%$ \\
\hline Zakupy z rodzicami & $\mathbf{2 2 \%}$ & $4,2 \%$ \\
\hline
\end{tabular}

* Dane w tabeli nie sumują się do 100\%, gdyż respondenci podawali więcej niż jedną odpowiedź. Źródło: opracowanie własne.

Niepokojąca - zarówno w Polsce (44\%), jak i w Portugalii (31,3\%) - jest tendencja do wypełniania czasu wolnego oglądaniem telewizji i graniem w gry komputerowe. Coraz bardziej popularne wśród dzieci, przede wszystkim portugalskie, staje się wysyłanie e-maili i SMS-ów do przyjaciół i kolegów. Być może deficyt czasu wolnego, zarezerwowany dotychczas dla dorosłych, zaczyna dotykać również i dzieci w wieku wczesnoszkolnym, które nie mogą znaleźć chwili na bezpośredni kontakt $\mathrm{z}$ rówieśnikami. Tylko około $12 \%$ badanych ma czas na spotkania i zabawy ze znajomymi lub rodzeństwem. Przeprowadzone badania dowodzą, że bezpośrednie kontakty, nawet i te, które tego nie wymagają, zastępowane są przez formę pośrednią, zmediatyzowaną - jak to określa Barbara Kita (2003, s. 23) - różnymi środkami komunikacji. Usytuowanie geograficzne danych miejsc przestaje mieć znaczenie. Kontaktowanie się przez pocztę elektroniczną jest wykorzystywane nie tylko w sytuacji znacznych odległości, z kimś będącym daleko, ale często także z kimś, kto znajduje się blisko. Relacje na odległość zastępują zasadę bezpośredniości.

Duży odsetek dzieci portugalskich (29,2\%) uprawia sport, głównie piłkę nożną, pływanie, rugby, tenis, i regularnie uczestniczy w treningach. W Polsce zaledwie 
6\% respondentów systematycznie uczęszcza na treningi organizowane w klubach sportowych. Dostrzeżone różnice niewątpliwie są uwarunkowane kulturowo - mają związek z nieco odmienną obyczajowością, np. piłka nożna, w Polsce nie jest aż tak popularna jak w Portugalii. Inne wymieniane przez portugalskie dzieci zajęcia to: zabawy z użyciem tabletu, zabawy na plaży, jazda na rowerze, zabawy w ogrodzie i na placu zabaw, zabawy z rodzeństwem i rówieśnikami. Czynnościami podejmowanymi najrzadziej są: czytanie ulubionych książek, zabawy z psem oraz wyjścia $\mathrm{z}$ rodzicami do restauracji.

Wśród dzieci polskich popularną formę spędzania czasu wolnego - oprócz tych wcześniej wymienionych - stanowią wypady z rodzicami na zakupy do różnych centr handlowych ( $22 \%$ badanych). Najmniej popularnym zajęciami - podobnie jak u rówieśników portugalskich - są czytanie książek oraz zajmowanie się zwierzętami domowymi (po 8\% badanych).

Przeprowadzone badania miały również na celu poznanie preferencji respondentów odnośnie do miejsca i sposobu spędzania czasu wolnego. Poproszono dzieci o dokonanie wyboru między zabawami poza domem, na łonie natury a oglądaniem telewizji/graniem na komputerze w domu. Uzyskane wyniki prezentuje tabela 3.

Tabela 3. Zabawy na łonie natury vs granie na komputerze/oglądanie telewizji - wybory dzieci

\begin{tabular}{|l|c|c|}
\hline \multicolumn{1}{|c|}{ Kategorie } & $\begin{array}{c}\text { Dzieci polskie } \\
\mathrm{N}=50\end{array}$ & $\begin{array}{c}\text { Dzieci portugalskie } \\
\mathrm{N}=48\end{array}$ \\
\hline Zabawy poza domem & $30 \%$ & $80,8 \%$ \\
\hline Komputer/oglądanie telewizji & $70 \%$ & $19,2 \%$ \\
\hline
\end{tabular}

Źródło: opracowanie własne.

Powyższe wybory respondentów dowodzą, iż świadomość uczniów dziewięcioletnich w kwestii odpowiedzialnego gospodarowania czasem wolnym jest większa wśród respondentów portugalskich niż polskich. Dzieci portugalskie w znakomitej większości $(80,8 \%)$ opowiedziały się za zabawami na łonie natury, natomiast dzieci polskie - za oglądaniem telewizji i grami komputerowymi (70\%). Wyłoniły się też różnice w jakości motywowania dokonanych wyborów.

Przykładowe wypowiedzi badanych:

- „Wybrałbym zabawę poza domem, bo mógłbym się wtedy dowiedzieć więcej rzeczy o miejscu, w którym mieszkam, a kiedy gram na komputerze, nie wiem, co się dzieje na zewnątrz. Zabawy na świeżym powietrzu są dobre dla naszego organizmu, podczas gdy granie na komputerze jest szkodliwe dla oczu" (Portugalia, chłopiec); 
- „Więcej czasu spędzam w domu, oglądając telewizję i grając w gry, ponieważ dzięki grom i filmom uczę się angielskiego i historii Portugalii. Wolałbym jednak bawić się z kolegami na podwórku, bo tak rzadko się z nimi widuję" (Portugalia, chłopiec);

- „Najwięcej czasu wolnego spędzam na podwórku, bo uwielbiam psy i mam kilka, więc bawię się z najmłodszą suczką jej piłką, i mam swoje roślinki, i w ten sposób lepiej oddycham" (Portugalia, dziewczynka);

- „Wybrałabym zabawę na ulicy, bo kiedy dorosnę, nie chcę być uzależniona od telewizji i gier komputerowych" (Portugalia, dziewczynka);

- „Wybrałbym oglądanie telewizji w domu, bo mógłbym wtedy położyć się na sofie i zasnąć" (Polska, chłopiec);

- „W czasie wolnym lubię czytać, lubię spacerować, bawić się i spędzać czas z rodziną" (Polska, dziewczynka);

- „Wolę komputer, bo mogę grać, rozmawiać z kolegami i bawić się” (Polska, chłopiec);

- „Wybrałabym zabawę na świeżym powietrzu, ponieważ lubię bawić się z koleżankami i miło spędzać czas" (Polska, dziewczynka).

Argumentacje dzieci polskich są na ogół krótkie i infantylne w przeciwieństwie do uzasadnień podawanych przez rówieśników z Portugalii, których wypowiedzi są bardziej rozbudowane, rzeczowe, oparte na wiedzy leżącej u podstaw rozumienia i nadawania określonego sensu podejmowanym przez respondentów działaniom. W tym miejscu warto postawić pytanie: „Dlaczego tak duży odsetek dzieci portugalskich, a tak niewielki odsetek dzieci polskich deklaruje zabawy na łonie natury i rezygnuje z telewizji oraz komputera?".

Wydaje się, że przyczyny tkwią w głównej mierze w edukacji, która jest - jak stwierdza Ryszard Łukaszewicz (1995, s. 82) - „instrumentem układania się człowieka ze światem, w następstwie czego wzrastają jego szanse samorealizacji w ekologicznym porządku życia”. Uzyskane wyniki badań pokazują, że edukacja na temat czasu wolnego w Polsce pozostaje na niskim poziomie i daje nikłe szanse na samorealizację w biodynamicznym świecie. Polacy wiele mówią o ekologii, zdrowym stylu życia, rozsądnym zarządzaniu czasem wolnym, jednakże mają problemy z wykorzystaniem wiedzy w praktyce, w życiu codziennym ${ }^{7}$. W polskich miastach i miasteczkach jest dużo terenów zielonych, lecz widzimy tam wiele zakazów

7 Dowodem małej skuteczności edukacji przyrodniczej są niezadowalające wyniki Międzynarodowego Badania Wyników Nauczania Matematyki i Nauk Przyrodniczych - TIMSS (ang. Trends in International Mathematics and Science Study) przeprowadzonego w 2011 roku w zakresie osiągnięć przyrodniczych dzieci kończących edukację wczesnoszkolną. Okazuje się, że polskich uczniów klas III szkół podstawowych wyprzedzają m.in. rówieśnicy ze Słowacji, Holandii, Niemiec, Danii, Włoch oraz Portugalii. 
i nakazów. Większość z nich dotyczy właśnie zabaw dzieci: nie wolno kopać piłki, nie wolno jeździć na rowerach, nie wolno dotykać drzew i krzewów, a w skrajnych przypadkach nie wolno nawet siadać na trawie. Przestrzeń miejska niestety nie zachęca dzieci do swobodnego kontaktu z naturą, będącego niezbędnym elementem ich prawidłowego rozwoju, a dorośli prawdopodobnie nie widzą potrzeby, by tę chorą sytuację uzdrowić.

Wiele niepokoju związanego z dysponowaniem czasem wolnym wzbudzają następujące głosy respondentów:

- „Raczej rodzice decydują o tym, co mam robić i nie zawsze jestem z tego powodu szczęśliwy. Kiedyś chciałem chodzić na pływanie, teraz wolałbym coś innego. Muszę chodzić do tego klubu, bo rodzice za to płacą" (Portugalia, chłopiec);

- „Gdybym mogła, wybierałabym zabawę poza domem, bo świeże powietrze jest dobre dla wszystkich, ale to rodzice decydują, gdzie mam być" (Portugalia, dziewczynka);

- „Nie mogę wybrać żadnej z tych opcji, bo albo pomagam mamie sprzątać dom, albo zajmować się moją siostrą. Gdybym jednak mogła, wybrałabym oglądanie telewizji. Lubię seriale i takie inne filmy" (Polska, dziewczynka).

Oczywiste jest to, że na rodzicach spoczywa obowiązek ukierunkowywania potrzeb i kształtowania nawyków właściwego spędzania czasu wolnego u swoich dzieci. Jednakże niepokojące wydają się te wypowiedzi, z których wynika, że niektórzy respondenci - mieszkający zarówno w Polsce, jak i w Portugalii - nie mają możliwości dokonywania wyboru miejsca czy rodzaju aktywności zgodnie ze swoimi preferencjami. Wydaje się, że dorośli nie wsłuchują się w głosy swoich dzieci, a tkwiąc w przekonaniu, iż wiedzą lepiej, nie traktują sygnalizowanych przez nie potrzeb z należytą uwagą, bagatelizują je. Brak prawa głosu dotyczy nie tylko czasu wolnego, ale również innych codziennych praktyk życia społecznego (Maciejewska-Mroczek 2012, s. 39). Tego rodzaju zachowania uzależniają dzieci od rad i zaleceń dorosłych, nie pozwalają na inicjatywę, kreatywność, doświadczanie poczucia sprawstwa, ujawniają natomiast wartości, zapatrywania i postawy znaczących innych, w tym przypadku rodziców. Uprawomocnienie prawa głosu dzieci, zwłaszcza w sprawach ich dotyczących, jest zgodne $\mathrm{z}$ tendencją w naukach społecznych, którą charakteryzuje „stopniowy odwrót od komparatystycznego zainteresowania taksonomiami i systemami politycznymi i skupienie się na praktykach i kodach władzy, a zwłaszcza na roli, jaką odgrywają w nich aktorzy społeczni” (Herzfeld 2004, s. 176). Należy mieć nadzieję, że wszyscy respondenci - aktorzy społeczni zostaną przez dorosłych z należytą uwagą wysłuchani. 
Samodzielne wykorzystanie czasu wolnego daje poczucie swobody, uczy odpowiedzialności za siebie i innych, rozwija inicjatywę, pozwala na autentyczne bycie sobą, na spontaniczność i wolność. Zaplanowane przez dzieci sposoby spędzania czasu wolnego stanowią doskonałą szkołę gospodarowania czasem, jak również nabywania tak bardzo dzisiaj pożądanej umiejętności wypoczywania.

\section{DOŚWIADCZANIE CZASU WOLNEGO W PRZYRODZIE}

Co się stanie, gdy za jakiś czas dzieci zostaną pozbawione zabaw w błocie, pokrzyw, ostów i nieba? Co się stanie, gdy nie będą już miały czasu na zabawę ani przestrzeni do niej? Co wtedy będzie? Kultura czasu wolnego ulega metamorfozie i oferuje coraz mniej możliwości przebywania na świeżym powietrzu. Zmienia się też sposób rozumienia i doświadczania przyrody przez dzieci. Ich fizyczny kontakt $\mathrm{z}$ otoczeniem staje się coraz rzadszy; jest on zamieniany na doświadczanie świata za pośrednictwem mass mediów. W ich codziennym życiu coraz więcej miejsca zajmują światy zapośredniczane, które eliminują osobiste doświadczenia w naturze. Zapośredniczenie zawiera w sobie kilka różnych elementów, odnosi się do przekazywania wiedzy z drugiej ręki (albo pochodzącej od osoby trzeciej) bądź relacjonowania wydarzeń i okoliczności, których nie możemy sami bezpośrednio obserwować.

$\mathrm{Na}$ zadane respondentom pytanie dotyczące częstotliwości przebywania w otoczeniu przyrody ponad $40 \%$ odpowiada, że bywa na podwórku, w parku lub w lesie raz w tygodniu, ponad $20 \%$ - dwa lub trzy razy w miesiącu, a tylko około $30 \%$ badanych - prawie codziennie.

Richard Louv (2008) stwierdza, że w społeczeństwie amerykańskim w ciągu zaledwie sześciu lat (między 1997 a 2003 rokiem) liczba dzieci, które spędzają czas na wolnym powietrzu, grając w piłkę, łowiąc ryby, wędrując lub pracując w ogrodzie, zmniejszyła się o połowę. Ponad 70\% amerykańskich matek pamięta, że codziennie bawiły się na podwórku, ale tylko $26 \%$ przyznaje, że bawią się tam też ich dzieci. Rolę podwórka przejęły teraz urządzenia elektroniczne. Zostało to określone jako problem „deficytu przyrody”. Pozbawianie dzieci kontaktu z przyrodą i możliwości zabawy na łonie natury można wręcz uznać za równoznaczne $\mathrm{z}$ ograniczaniem im dostępu do powietrza (Louv 2014, s. 137). Przeprowadzone w Polsce i Portugalii badania dowodzą, że nakreślony przez Amerykanów problem rozprzestrzenia się i zaczyna być coraz bardziej zauważalny również w Europie.

Przyroda rozumiana jako dar Boga ma również cel edukacyjny, służy wychowaniu i wykształceniu człowieka, poznaniu Boga: 
Świat nie istnieje na darmo ani na próżno, lecz został wymyślony dla jakiegoś pożytecznego celu i z powodu wielkiej potrzeby dla bytów: świat jest szkołą dla dusz rozumnych i miejscem nauki, gdzie poznaje się Boga, gdzie umysł jest prowadzony za rękę od rzeczy widzialnych i dostępnych zmysłom do kontemplacji niewidzialnych (Osek 2009, s. 74).

Szkoda, że metafora szkoły użyta w odniesieniu do przyrody staje się coraz mniej obecna w wychowaniu i edukacji współczesnego dziecka.

Respondenci z Polski i z Portugalii pozostają na ogół zgodni co do tego, że przyroda jest człowiekowi niezbędna do życia. Różnice ujawniają się w argumentacji. Przykładowe wypowiedzi dzieci prezentuje tabela 4:

Tabela 4. Znaczenie przyrody - głosy dzieci

\begin{tabular}{|l|l|}
\hline \multicolumn{1}{|c|}{ Wypowiedzi dzieci portugalskich } & \multicolumn{1}{|c|}{ Wypowiedzi dzieci polskich } \\
\hline $\begin{array}{l}\text { „To spokojne, piękne miejsca, możemy urządzać pik- } \\
\text { niki, obserwujemy przyrodę i więcej się o niej uczymy” } \\
\text { (chłopiec) }\end{array}$ & $\begin{array}{l}\text { „Przyroda jest ważna, bo bez drewna nie ma opału do } \\
\text { kominków dla ludzi, którzy nie mają w domu innego } \\
\text { ogrzewania” (chłopiec) }\end{array}$ \\
\hline $\begin{array}{l}\text { „Słyszę odgłosy przyrody, oddycham bardzo świeżym } \\
\text { powietrzem, słyszę śpiew ptaków i szum wodospadów. } \\
\text { Przyroda sprawia, że czuję się wolny” (chłopiec) }\end{array}$ & $\begin{array}{l}\text { „Uważam, że przyroda jest człowiekowi potrzebna, } \\
\text { bo bez drzew nie oddychalibyśmy, bo to one dają tlen, }\end{array}$ \\
\hline $\begin{array}{l}\text { „Dzięki przyrodzie mam więcej przestrzeni na zabawę oddycha” (dziewczynka) } \\
\text { i żeby odpocząć. Widzimy kwiaty w wesołych kolorach } \\
\text { i dowiadujemy się więcej o zwierzętach i o przyrodzie”” } \\
\text { (dziewczynka) }\end{array}$ & „Bez wody umarlibyśmy, a rośliny są nam potrzebne \\
\hline $\begin{array}{l}\text { "Mogę spotkać różne gatunki roślin, oglądam zwie- } \\
\text { rzęta, lubię patrzeć na tęczę i na jeziora” (dziewczynka) }\end{array}$ & „Przyroda daje nam pożywienie” (dziewczynka) \\
\hline $\begin{array}{l}\text { „Oczywiście przyroda jest ważna, bo wszystko jest czę- } \\
\text { ścią przyrody, jak my, zwierzęta i rośliny” (chłopiec) }\end{array}$ & $\begin{array}{l}\text { "Bez przyrody nikt nie miałby tlenu i przez to nie } \\
\text { byłoby ludzi na świecie” (chłopiec) }\end{array}$ \\
\hline
\end{tabular}

Źródło: opracowanie własne.

Jak wynika z powyższych wypowiedzi, dzieci portugalskie doceniają przyrodę głównie z uwagi na jej piękno, różnorodność, tajemniczość i artyzm. Utożsamiają się z nią, czując się jej częścią. Dzieci mieszkające w Polsce koncentrują się przede wszystkim na korzyściach, jakie człowiek czerpie z przyrody. Ich wypowiedzi wskazują na utylitarny stosunek do natury.

\section{PODSUMOWANIE}

Przyszło nam żyć w świecie, który oferuje wyjątkową obfitość bodźców, skoncentrowanych głównie na zmysłach wzroku i słuchu. Niemal codziennie przybywają nowe możliwości poznawania ludzi i zdobywania wiedzy, niestety przeważnie 
z wykorzystaniem elektronicznych technologii, szczególnie Internetu oraz nowych mediów. W społeczeństwie tak bardzo szybko się zmieniającym i oferującym mnóstwo rozmaitych możliwości granice między czasem wolnym a pracą zaczynają być niewyraźne, przeobrażeniom ulegają zachowania uczestników życia społeczno-kulturowego.

Przeprowadzone badania nad czasem wolnym respondentów mieszkających w Polsce i Portugalii budzą pewien niepokój. Utwierdzają w przekonaniu, że codzienna przestrzeń dziecka poszerza się gwałtownie o nowe media i multimedia. Media elektroniczne towarzyszą dzieciom codziennie, wypełniając nie tylko ich czas wolny, ale również czas zajęć obowiązkowych. Wszystko to staje się odmianą specyficznej bliskości, obcowaniem ze światem „w zasięgu ręki” - w domu. Ograniczona przestrzeń unieruchamia, usztywnia dziecko, pobudza zachowania konsumpcyjne.

Dostrzeżone problemy wskazują na to, iż dzieciństwo traci swój dawny blask, nie wydaje się ani pożądane, ani konieczne. Współczesne dzieci, bogate w urządzenia elektroniczne oraz liczne propozycje edukacyjne, są nieprawdopodobnie ubogie w czas wolny, tak bardzo istotny szczególnie dla zdrowia psychicznego. Wartość pedagogiczna czasu wolnego polega na tym, że powinien on dawać dzieciom możliwość wytchnienia po pracy w szkole, przejawiania własnej inicjatywy i samodzielności, rozbudzania aktywności, kreatywności i umiejętności organizowania sobie zajęć. Tymczasem dorośli

popadają wręcz w edukacyjną histerię, chcąc jak najlepiej przygotować dziecko do spełniania wymogów stawianych przez współczesność. Rozpoczynają wszechstronną edukację swoich dzieci możliwie jak najwcześniej - już nawet w wieku niemowlęcym. Natomiast później oprócz edukacji szkolnej angażują swoje pociechy w szereg zajęć pozalekcyjnych [...]. W zależności od ambicji i zasobności portfela rodziców dzieci muszą dorastać na skróty i jak najszybciej podejmować konkurencyjne zmagania, by odnieść sukces (Malorny 2010, s. 489).

Podobną opinię w tej kwestii wyraża również Hanna Jaklewicz (2009, s. 148), pisząc, że obecnie zagwarantowanie „dziecku szczęścia i realizacja jego potrzeb sprowadza się do budowania podstaw bytu materialnego i przygotowania do rywalizacji. Dziecko jest inwestycją. Konsekwencją takiego stosunku do dziecka jest jego przedwczesna dojrzałość i samotność".

Wydaje się, że dzisiejszy świat potrzebuje nowej kultury czasu wolnego - zarówno dzieci, jak i dorosłych - która zakłada dokonanie przewartościowania, zmianę w sposobie myślenia wielu osób, respektowanie potrzeb biologicznych człowieka (życie w zgodzie z rytmem organizmu), a oprócz tego zaistnienie nowych ramowych 
warunków politycznych i społecznych (Klein 2009, s. 260-261). Wyjątkowo istotna wydaje się edukacja mająca na celu uświadamianie dzieciom ich własnych upodobań i zainteresowań, motywowanie do wchodzenia w role architektów swojego czasu oraz umiejętne dokonywanie wyborów, z których składa się życie codzienne. Niezależnie od tego, na co przeznaczymy najmniejszy ułamek naszego czasu wolnego, będzie on stracony dla czegoś innego. „Wszystko w życiu można pomnażać - tylko czasu się nie da" (Klein 2009, s. 222).

Paradoksalnie rozwój cywilizacji, mimo że przynosi wiele udogodnień, ogranicza wolność i swobodę dziecka. Częstokroć skazuje na izolację i samotność, wprowadza zmiany w sposobach rozumienia i spędzania czasu wolnego, który - jak pokazują przeprowadzone badania - jest czasem pozornie wolnym, hermetycznie zaplanowanym i zorganizowanym przez rodziców. Taki narzucony, przeładowany harmonogram zajęć pozaszkolnych, nawet bardzo atrakcyjny, nie uszczęśliwi dziecka, wręcz przeciwnie - może skutkować frustracją.

\section{LITERATURA}

Bańka A., 2002, Społeczna psychologia środowiskowa. Warszawa, Wydawnictwo Naukowe Scholar.

Buber M., 1968, Wychowanie, „Znak” 166 (4) , 447-449.

Cieloch G., Kuczyński J., Rogoziński K., 1992, Czas wolny - czasem konsumpcji? Warszawa, Państwowe Wydawnictwo Ekonomiczne.

Czerepaniak- Walczak M., 2007, Od próżniaczenia do zniewolenia - w poszukiwaniu dyskursów czasu wolnego. W: E. Marynowicz-Hetka (red.), Pedagogika społeczna. Podręcznik akademicki, t. 2. Warszawa, Wydawnictwo Naukowe PWN, 219-236.

Durozoi G., Roussel A., 1997, Filozofia: słownik: pojęcia, postacie, problemy. Warszawa, WSiP.

Gagacka M., 2007, Czas wolny studentów - preferencje i uwarunkowania. W: K. Ciżkowicz, M. Sobczak (red.), Czas wolny - uwarunkowania społeczno-ekonomiczne i przyrodnicze. Bydgoszcz, Wydawnictwo Uczelniane WSG.

Grochociński M., 1980, Rodzina a czas wolny. Gdańsk, KAW.

Herzfeld M., 2004, Antropologia: praktykowanie teorii w kulturze i społeczeństwie. Kraków, Wydawnictwo UJ.

Jaklewicz H., 2009, O kulturowej zmienności wzorów relacji z dzieckiem. W: M. Ejsmond, B. Kosmalska, M. Mendel (red.), Obraz, przestrzeń, popkultura. Inspiracje badawcze w polu pedagogiki społecznej. Toruń, Wydawnictwo Adam Marszałek, 144-148. 
Kazimierczak M., 2007, Czas wolny w etycznej perspektywie. W: K. Ciżkowicz, M. Sobczak (red.), Czas wolny - uwarunkowania społeczno-ekonomiczne i przyrodnicze. Bydgoszcz, Wydawnictwo Uczelniane WSG, 15-21.

Kita B., 2003, Między przestrzeniami. O kulturze nowych mediów. Kraków, Wydawnictwo Rabid.

Klein S., 2009, Czas: przewodnik użtkownika. Warszawa, Wydawnictwo W.A.B. Louv R., 2008, Last Child in the Woods: Saving Our Children From Nature-Deficit Disorder. Chapel Hill, Algonquin Books.

Louv R., 2014, Ostatnie dziecko lasu. Jak uchronić nasze dzieci przed zespołem deficytu natury. Warszawa, Wydawnictwo Relacja.

Łukaszewicz R., 1995, Edukacja z wyobraźnią, czyli jak podróżować bez map. Wrocław, Wydawnictwo UWr.

Maciejewska-Mroczek E., 2012, Mrówcza zabawa. Współczesne zabawki a społeczne konstruowanie dziecka. Kraków, TAiWPN Universitas.

Malorny I., 2010, Zjawisko atomizacji społecznej i moralnej w obszarze współczesnych działań pedagogicznych. W: J. Piekarski, T. Pilch, W. Theiss, D. Urbaniak-Zając (red.), Edukacja społeczna wobec problemów współczesnego człowieka i społeczeństwa. Łódź, Wydawnictwo UŁ, 479-490.

Osek E., 2009, Przyroda w pismach Bazylego Wielkiego. Lublin, Towarzystwo Naukowe KUL.

Pabian B., Z problemów czasu wolnego współczesnej polskiej rodziny. W: W. Muszyński (red.), Rodzina w świecie wartości. Religia, praca i czas wolny. Toruń, Wydawnictwo Adam Marszałek, 337-349.

Przecławski K., 1993, Czas wolny dzieci i młodzieży. W: W. Pomykało (red.), Encyklopedia pedagogiczna. Warszawa, Wydawnictwo Fundacja Innowacja, 75-77.

Schütz A., 2008, O wielości światów. Kraków, Zakład Wydawniczy Nomos.

Smolińska-Theiss B., 2014, Dzieciństwo jako status społeczny: edukacyjne przywileje dzieci klasy średniej. Warszawa, Wydawnictwo APS.

Szpet G., 2013, Wewnętrzna forma słowa. Gdańsk, Wydawnictwo UG.

Tischner J., 1989, Fenomenologia. W: J. Tischner (red.), Filozofia współczesna. Kraków, Wydawnictwo Znak.

Truszkowska-Wojtkowiak M., 2012, Fenomen czasu wolnego. Gdańsk, Harmonia Universalis.

Tyszkowa M., 1988, Rozwój psychiczny jednostki jako proces strukturacji i restrukturacji doświadczenia. W: M. Tyszkowa (red.), Rozwój psychiczny człowieka $w$ ciagu życia. Zagadnienia teoretyczne i metodologiczne. Warszawa, Wydawnictwo Naukowe PWN, 44-79.

Vasta R., Haith M.M., Miller S.A., 1995, Psychologia dziecka. Warszawa, WSiP. Yi-Fu T., 1987, Przestrzeń i miejsce. Warszawa, PIW. 


\title{
SPARE TIME AS ONE OF THE DIMENSIONS OF THE EVERYDAY LIFE OF CHILDREN LIVING IN POLAND AND PORTUGAL
}

\begin{abstract}
The objective of this article is to demonstrate the experiences of Polish and Portuguese children at an early-school age connected with the ways of spending their spare time after completing their daily school curriculum. Numerous research projects indicate the shrinking of spare time in families and the tendency to spend less and less time outdoors, in natural surroundings. Many researchers around the world have noticed that electronic media fill up not only the spare time of children, but are also used during classes. The issue at hand sheds light on the contemporary trends associated with the issue of spare time.
\end{abstract}

Keywords: spare time, mass media, child, nature, nature deficit 